\title{
ECC
}

Eurasian Chemical Communications

\section{2,2-Hydroxyphenylbenzoxazole as a selective chelating agent for complexation with Tin and Zinc: a voltammetry study}

\author{
Shahryar Abbasia, Somayeh Hamdeghadareha, Loghman Rezaei-Soufib, \\ Abbas Farmany,* \\ a Department of Chemistry, Faculty of Sciences, Ilam University, Ilam, Iran \\ ${ }^{b}$ Dental Research Center, Hamadan University of Medical Sciences, Hamadan, Iran
}

Received: 13 October 2019, Accepted: 02 November 2019, Published: 23 November 2019

\begin{abstract}
A highly selective and sensitive adsorptive stripping procedure for simultaneous determination of trace tin and zinc is presented in this study. The method is based on the adsorptive accumulation of the complexes of Sn (II) and $\mathrm{Zn}$ (II) ions with 2, 2 hydroxyphenylbenzoxazole (HBO) onto a hanging mercury drop electrode, followed by the reduction of the adsorbed species by differential pulse cathodic stripping voltammetry. The optimal experimental conditions include the use of $0.1 \mathrm{M}$ acetate buffer ( $\mathrm{pH} 5.0$ ), $2.0 \times 10^{-5} \mathrm{M} \mathrm{HBO}$, an accumulation potential of $-0.35 \mathrm{~V}$ (versus $\mathrm{Ag} / \mathrm{AgCl}$ ), an accumulation time of $90 \mathrm{~s}$ and a scan rate of $100 \mathrm{mV} / \mathrm{s}$. Under optimized conditions, linear calibration curves were established for the concentration of $\mathrm{Sn}(\mathrm{II})$ and $\mathrm{Zn}(\mathrm{II})$ in the range of $0.2-100.0 \mu \mathrm{g} / \mathrm{L}$ and $0.1-120.0 \mu \mathrm{g} / \mathrm{L}$, respectively, while the detection limit is $0.09 \mu \mathrm{g} / \mathrm{L}$ for tin and $0.01 \mu \mathrm{g} / \mathrm{L}$ for zinc for a $90 \mathrm{~s}$ adsorption time. The method was applied to the determination of tin and zinc in biological samples with satisfactory results.
\end{abstract}

Keywords: 2, 2-Hydroxyphenylbenzoxazole; tin; zinc; voltammetry.

\section{Introduction}

Heavy metals are natural components of earth's crust. They cannot be degraded or destroyed to a small extent. They enter our bodies via foods, drinking water and air. As trace elements, some heavy metals (e.g. copper and zinc) are essential to maintain the metabolism of human body. However, at higher concentrations, they can be toxic. Heavy metals poisoning can result, for instance, from drinking water contamination (e.g. lead pipes, $\mathrm{Cd}$ from glass ceramics ware), high ambient air concentrations near emission sources, or intake via food chain. Heavy metals are dangerous because they tend to bio accumulate. Although tin is not a highly toxic element, high concentration of tin can cause diarrhea. The main source of tin uptake by man is food, the exception being some polluted industrial areas, where tin concentration in water and air is high. The maximum tolerance level of tin in food defined by the WHO is $250 \mu \mathrm{g} / \mathrm{g}$ and the tin contents in environmental and biological samples cover a wide range, reaching from $\mu \mathrm{g} / \mathrm{g}$ quantities in

*Corresponding author: Abbas Farmany

Tel: +98 (81) 38394619, Fax: +98 (81) 38394619

Eurasian Chem. Commun., (2020) 128-137

E-mail: a.farmany@ut.ac.ir 
canned foods down to $\mathrm{ng} / \mathrm{g}$ and even $\mathrm{Pg} / \mathrm{g}$ quantities in water [1]. For this reason, a highly sensitive and selective method is required for reliable measurement of tin. Environmental elements such as tin and zinc ions have been tested and assessed over the past few years from both the toxicological and human health view point. Zinc is relatively rare in nature, but has a long history of use. Its compounds are widely used in, for example electroplating, pharmaceuticals, paints, rubber, dye, wood preservatives, ointments and battery industries [2]. Also, zinc is present in high protein foods. Human body contains around 2.0 $\mathrm{g}$ zinc and its large doses can cause fever, chills, pulmonary manifestation and gastroenteritis. It can also cause vomiting, nausea, anemia, renal failure and internal organ damage. Several analytical techniques, such as atomic absorption spectrometry (AAS) [3], thermo-spray flame furnace atomic spectrometry [4], inductive coupled plasma- mass spectrometry (ICP-mass) [5], voltammetric methods [6-14] etc., are available for the quantification of tin and zinc. However, maintenance and operational cost of these techniques are expensive and require adequate expertise. Therefore, the analysis is often limited to the laboratory level only. Electrochemical methods have shown numerous advantages including speed of analysis, good selectivity and sensitivity, good performance with saline matrixes like river water and the possibility of simultaneous analysis of mixtures [15,31]. At this time, a few organic compounds such as Morin [6], mixture of dimethylglyoxim and oxine [7], cupferron [8], catechol [16], tropolone [17,18], chloranilic acid [19], propyl gallate [20], phenylfluorone [21] and 8-hydroxyquinoline [22] as complexing agent have been reported for the determination of zinc and tin ions at ultra-trace level. In this paper, a novel adsorptive stripping voltammetry method is reported for the simultaneous quantification of tin and zinc. The method is based on the reduction of the complexes of metal ions with HBO (Figure 1) after accumulation at the surface of a hanging drop mercury electrode. This method was used for simultaneous determination of both metal ions in biological samples with the satisfactory results.

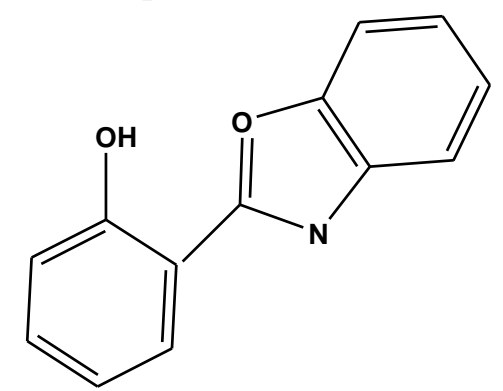

Figure 1. Structural formula of 2, 2-hydroxyphenylbenzoxazole (HBO)

\section{Experimental}

Materials and methods

Apparatus and reagents

Stripping voltammetric experiments were carried out with a Metrohm (Herisau, Switzerland) VA Stand 747 polarographic connected to a Metrohm
Trace Analyser 746 control unit. Multimode electrode was used in the hanging mercury drop electrode (HMDE) mode. Platinum rod and $\mathrm{Ag} / \mathrm{AgCl}, \mathrm{KCl}$ salt electrodes were used as auxiliary and reference electrode, respectively. $\mathrm{pH}$ measurements were 
made with a Metrohm Model $780 \mathrm{pH}$ meter. Solutions were prepared by dissolving analytical grade reagents in double distilled water. A $1 \times 10^{-3} \mathrm{M}$ HBO (Merck) was prepared by dissolving appropriate amount of HBO in $100.0 \mathrm{~mL}$ double distilled water. Stock solutions of tin and zinc (1000 $\mathrm{mg} / \mathrm{L})$ were prepared by dissolving appropriate amount of tin chloride and zinc nitrate salts in water and diluting to $100.0 \mathrm{~mL}$ in a volumetric flask (to prevent the hydrolysis of tin chloride and zinc nitrate salts in which 2 drop of nitric acid $0.02 \%$ was added). Standard solutions of tin and zinc were daily prepared by dilution of $(1000 \mathrm{mg} / \mathrm{L})$. Buffer solution was prepared from acetic acid and sodium acetate $(0.1 \mathrm{M})$.

\section{Adsorptive stripping procedure}

The sample solution $(10 \mathrm{~mL})$, containing $2.0 \times 10^{-5} \mathrm{M} \mathrm{HBO}$ and acetate buffer $(\mathrm{pH}=5.0)$ is pipetted into the voltammetric cell. The stirrer was switched on and the solution was purged with nitrogen gas for $4 \mathrm{~min}$. After forming a new HMDE, the accumulation potential of $-350 \mathrm{mV} v s$. $\mathrm{Ag} / \mathrm{AgCl}$ electrode was applied for 90 s. At the end of accumulation time, the stirrer was switched off and after $10 \mathrm{~s}$, at the some potential to allow equilibrium, the voltammetric curve were was recorded with negative going differential pulse.

\section{Results and discussion}

HBO is known to yield the defined complexes in the presence of different metals [28]. Figure 2 displays a cathodic stripping pulse voltammograms for the system. The blank solution (HBO and buffer) does not show any peak current in this potential range (Figure 2). A solution containing the metal ions (in the absence of HBO) in the buffer solution shows metal peak currents. With the addition of HBO to Sn (II) and Zn (II)buffer solution, as indicated in Figure 2, and two large cathodic peaks were obtained. The peak currents were increased with increasing accumulation time. The tin and zinc stripping peaks were registered at about -300 and -1000 $\mathrm{mV}$ vs. $\mathrm{Ag} / \mathrm{AgCl}$ respectively and the current was used as a measure of a $n$ a 1 y $\mathrm{t}$ i c a 1 s i g n a 1 .

\section{Adsorptive characteristic of Sn and Zn-HBO complexes}

Preliminary experiments were carried out to identify the general features, which characterize the behaviour of the $\mathrm{Sn}$ and $\mathrm{Zn}-\mathrm{HBO}$ system on mercury drop electrode. Figure 2a shows the voltammograms of a solution containing $2.0 \times 10-5 \mathrm{M} \mathrm{HBO}$ at $\mathrm{pH} 5.0$ (acetate buffer) after $50 \mathrm{~s}$ accumulation at $-100 \mathrm{mV}$. As illustrated in Figure 2, tin and zinc reduction currents increased due to the addition of $\mathrm{HBO}$ to the solution. These responses increased when an accumulation time preceded the potential scan. These reduction currents increased linearly with increasing metal concentrations. With respect to the facts that the metal reduction currents increased due to the addition of HBO to the solution and the dependence of peak current on the accumulation time, it can be concluded that the metals-HBO complexes were adsorbed on the surface of electrode.

\section{Effect of operational parameters Effect of $p H$}

Among various electrolytes examined for adsorptive stripping study, the best results were obtained in acetate buffer media. The influence of $\mathrm{pH}$ on the cathodic stripping peaks currents of tin and zinc was studied in the $\mathrm{pH}$ range of 3.0-5.5 (Figure 2). It was found that at $\mathrm{pH}$ 5.0, the peak currents of tin and zinc were at the maximum value. Due to the metals hydroxide formation at higher 
$\mathrm{pH}$ and protonation of ligand at lower $\quad \mathrm{pH}$ values, the $\mathrm{pH} 5.0$ was selected.

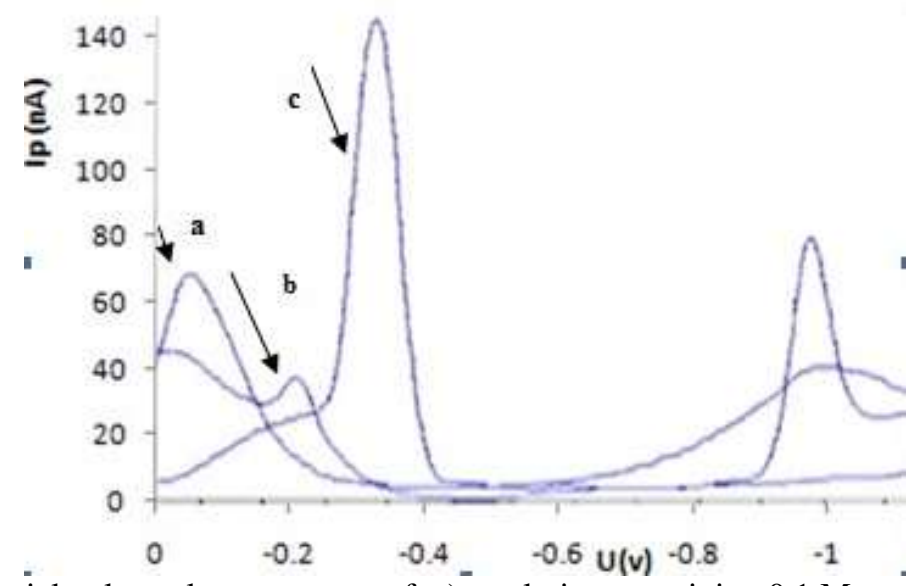

Figure 2. Differential pulse voltammograms of: a) a solution containing $0.1 \mathrm{M}$ acetate buffer $\mathrm{pH} 5.0$;

b) a solution containing $2.0 \times 10^{-5} \mathrm{M} \mathrm{HBO}$; c) solution containing 30 and $50 \mu \mathrm{g} / \mathrm{L}$ tin and zinc
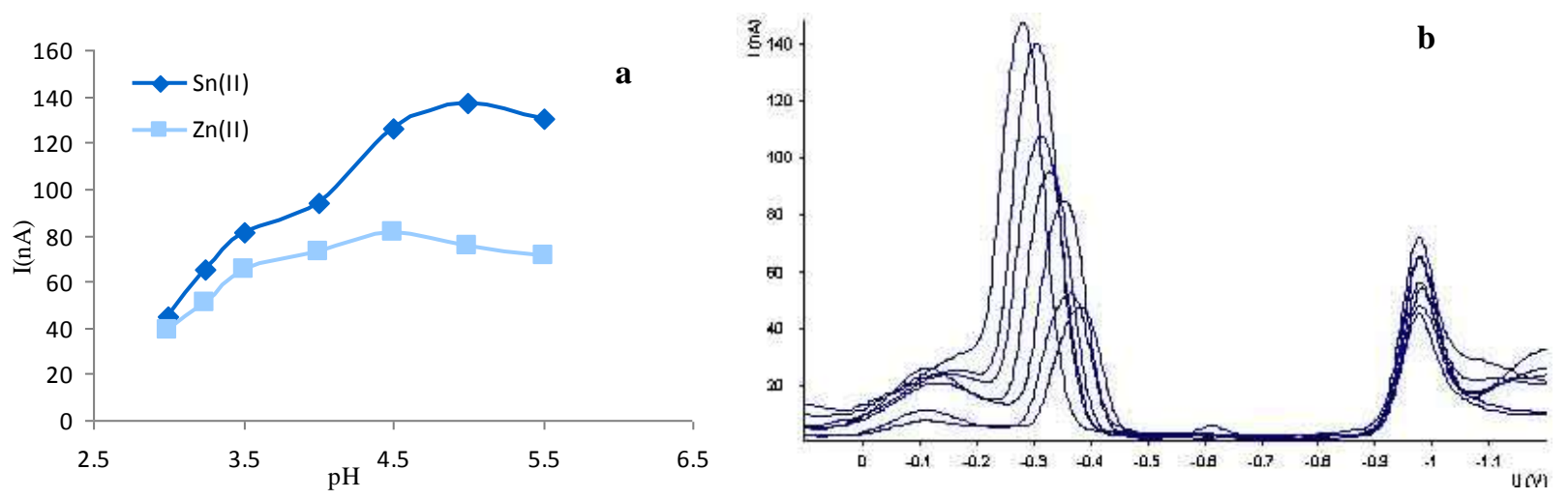

Figure 3. a) Dependence of peak heights on the $\mathrm{pH}$ value and b) related voltammograms. Conditions: $30 \mu \mathrm{g} / \mathrm{ml} \mathrm{Sn} \mathrm{(II),} 50 \mu \mathrm{g} / \mathrm{L} \mathrm{Zn} \mathrm{(II);} 1.0 \times 10^{-5} \mathrm{M}$ HBO; $\mathrm{E}_{\mathrm{acc}}=-100 \mathrm{mV} ; \mathrm{t}_{\mathrm{acc}}=50 \mathrm{~s}$.

\section{Effect of $H B O$ concentration}

The effect of HBO concentration on the sensitivity of proposed method was also studied. The results (Figure 4) show that the cathodic stripping peak currents of $\mathrm{Sn}$ and $\mathrm{Zn}-\mathrm{HBO}$ complexes were increased by increasing the $\mathrm{HBO}$ concentration up to $2.0 \times 10^{-5} \mathrm{M}$, leveloff at higher concentrations. An optimum $\mathrm{HBO}$ concentration of $2.0 \times 10^{-}$ ${ }^{5} \mathrm{M}$ was selected for further experiments. 


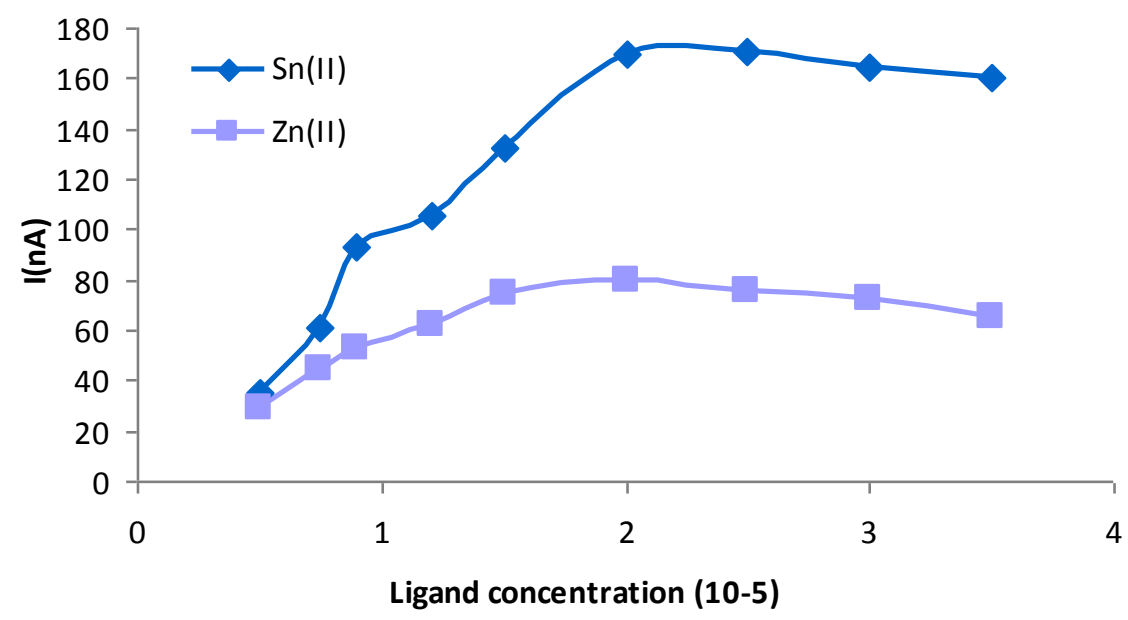

Figure 4. Dependence of peak heights on the ligand concentration. Conditions: $30 \mu \mathrm{g} / \mathrm{L}$ Sn (II), 50

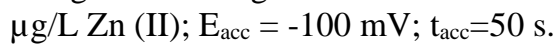

\section{Effect of accumulation potential}

The effect of accumulation potential on the peaks currents of tin and zinc was examined over the range from 0.0 to $450 \mathrm{mV}$. As can be seen in Figure 5, at the potential of $-350 \mathrm{mV}$ the peak currents were independent to the accumulation potential. As it is obvious, the peak currents are independent of accumulation potential at potentials more negative than -350 $\mathrm{mV}$. At this potential, the complexes were adsorbed on the surface of electrode and the response signals are due to the reduction of complexes during the cathodic sweep. So, an accumulation potential of $-350 \mathrm{mV}$ was used as the optimized analytical procedure.

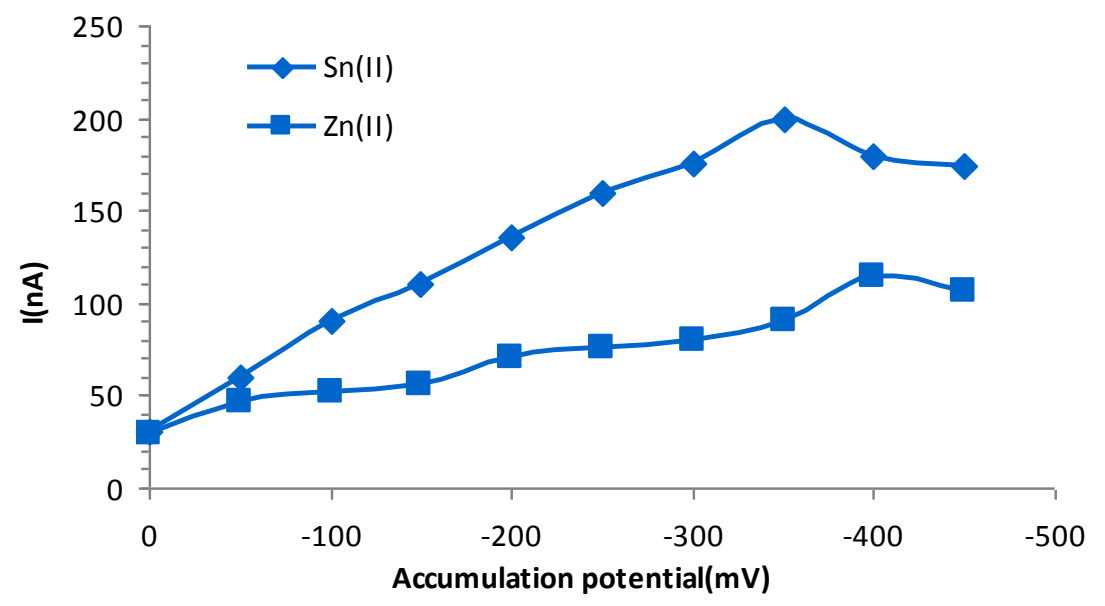

Figure 5. Dependence of peak heights on the accumulation potential. Conditions: $30 \mu \mathrm{g} / \mathrm{L} \mathrm{Sn}$ (II), 50 $\mu \mathrm{g} / \mathrm{L} \mathrm{Zn}(\mathrm{II}) ; 2.0_{\times} 10^{-5} \mathrm{M}$ HBO; $\mathrm{t}_{\mathrm{acc}}=50 \mathrm{~s}$.

Effect of accumulation time and scan rate

Figure 6 shows plots of the cathodic peak current in differential pulse voltammetry versus accumulation time and effect of scan rate on the sensitivity of the method, respectively. In Figure 6 , at first, the peak currents increased 
linearly with accumulation time indicating that before the adsorptive equilibrium is reached, the longer accumulation time, more metal-HBO was adsorbed and thus the peaks

currents become larger. However, after a specific period of accumulation time, the peaks currents tend to level-off; illustrating that the adsorptive equilibrium was achieved.
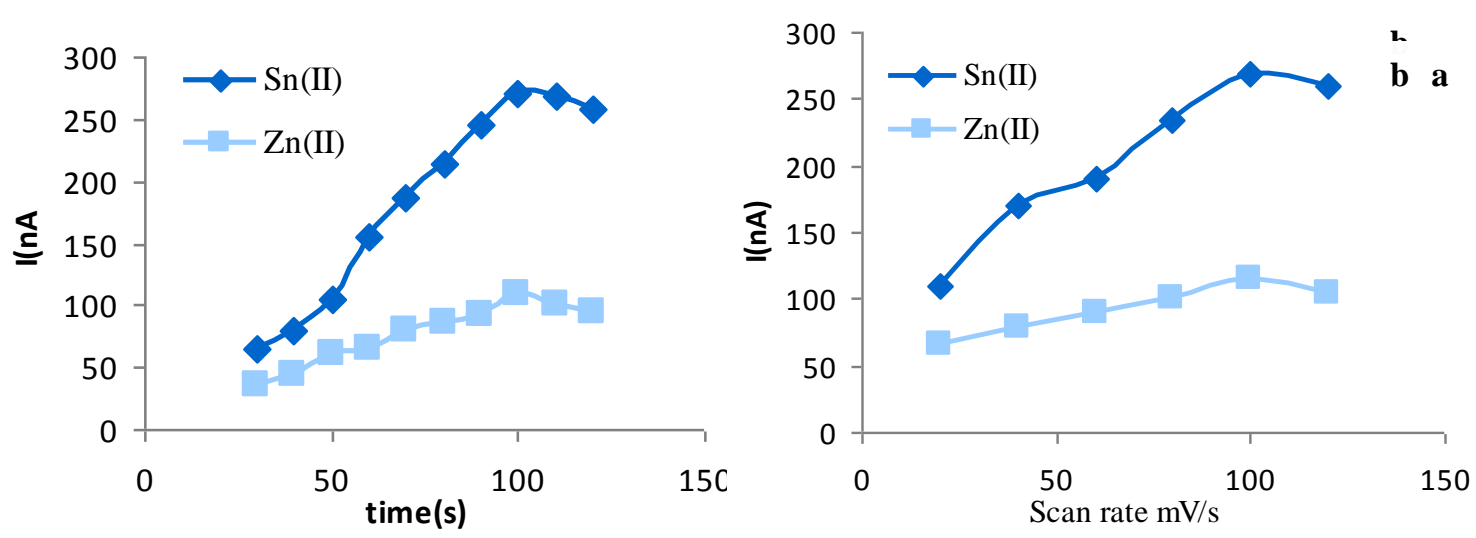

Figure 6: a) Dependence of peak heights on the accumulation time. Conditions: $30 \mu \mathrm{g} / \mathrm{L}$ Sn (II), 50 $\mu \mathrm{g} / \mathrm{L} \mathrm{Zn}(\mathrm{II}) ; 2.0_{\times} 10^{-5} \mathrm{M}$ HBO; $\mathrm{E}_{\mathrm{acc}}=-350 \mathrm{mV}$; b) Dependence of peak heights on the Scan rate.

Conditions: $30 \mu \mathrm{g} / \mathrm{L}$ Sn (II), $50 \mu \mathrm{g} / \mathrm{L} \mathrm{Zn} \mathrm{(II);} 2.0_{\times} 10^{-5} \mathrm{M} \mathrm{HBO} ; \mathrm{E}_{\mathrm{acc}}=-350 \mathrm{mV}, \mathrm{t}_{\mathrm{acc}}=90 \mathrm{~s}$.

Linear range and detection limit

To verify the linear relationship between peak currents and metal concentrations, calibration graphs were constructed under optimum conditions and $90 \mathrm{~s}$ accumulation times. The results of this study indicated that the current- concentration relationship $i=7.751 C_{S n}+10.31$ and $i=2.123 C_{Z n}$ +4.747 (correlation coefficients greater than 0.999) was linear in the concentration range of $0.2-100.0 \mu \mathrm{g} / \mathrm{L}$ for tin and $0.1-120.0 \mu \mathrm{g} / \mathrm{L}$ for Zinc. The detection limit (DL) of procedure was calculated based on the equation
$3 \sigma / m$, where $m$ is the slope of the calibration curve and $\sigma$ is the standard deviation of blanck. Detection limits of this method were obtained as 0.09 and $0.01 \mu \mathrm{g} / \mathrm{L}$ for tin and zinc, respectively.

\section{Interference studies}

Possible interferences by other metals with the cathodic adsorptive stripping voltammetry of tin and zinc was investigated by addition of the interfering ion to a solution containing $30.0 \mu \mathrm{g} / \mathrm{L}$ tin and $50.0 \mu \mathrm{g} / \mathrm{L}$ zinc using the optimized conditions. The results of the study are summarized in Table 1.

Table1. Maximum tolerable concentrations of interfering species

\begin{tabular}{lcc}
\hline Ions & Tolerance limit $\mathbf{S n}(\mathrm{II})$ & Tolerance limit $\mathbf{Z n}(\mathrm{II})$ \\
\hline $\mathrm{Br}^{-}, \mathrm{Cl}^{-}, \mathrm{SCN}^{-}, \mathrm{H}_{3} \mathrm{PO}_{4}^{-}, \mathrm{Na}^{+}, \mathrm{Cs}^{+}$, & 1000 & 1000 \\
$\mathrm{Ag}^{+}, \mathrm{Al}^{3+}, \mathrm{NO}_{2}^{-}, \mathrm{CLO}_{4}^{-}, \mathrm{SO}_{3}^{2-}, \mathrm{BrO}_{3}^{-}$ & & 500 \\
$\mathrm{Ni}^{2+}, \mathrm{Cu}^{+2}, \mathrm{Mg}^{2+}, \mathrm{NH}_{4}^{+}$ & 500 & 100 \\
$\mathrm{Fe}^{3+}, \mathrm{Co}^{2+}, \mathrm{Mn}^{2+}, \mathrm{Cr}^{3+}$, & 100 & 20 \\
$\mathrm{Cd}^{2+}, \mathrm{Pb}^{2+}$ & 20 & 12 \\
$\mathrm{Sn}^{4+}, \mathrm{Li}^{+}, \mathrm{I}^{-}$ & 12 & \\
\hline
\end{tabular}


Real sample analysis

The proposed method was successfully applied to the determination of tin and zinc in biological samples. Human hair samples $(\mathrm{Ca} .5 .0 \mathrm{~g})$ were first washed with acetone, chloroform, shampoo and water, then digested in solution containing $6 \mathrm{M} \mathrm{HClO}$ and $3 \mathrm{M} \mathrm{HNO}_{3}$ at $200{ }^{\circ} \mathrm{C}$ until the sample was colour- less, and heated to dryness. The human blood serum was prepared according to literature $[29,30]$. In order to eliminate the matrix effect, the standard addition method was used. The data obtained for samples, spiked with known amounts of tin and zinc, showed good recoveries (Table 2).

Table 2. Determination of tin and zinc in real samples-

\begin{tabular}{|c|c|c|c|c|c|c|}
\hline Sample & $\begin{array}{c}\text { Added } \\
\operatorname{Sn}(I I)(\mu g / L)\end{array}$ & $\begin{array}{c}\text { Added } \mathrm{Zn}(\mathrm{II}) \\
(\mu \mathrm{g} / \mathrm{L})\end{array}$ & $\begin{array}{l}\text { Found } \\
\operatorname{Sn}(I I) \\
(\mu \mathrm{g} / \mathrm{L})\end{array}$ & $\begin{array}{l}\text { Found } \\
\text { Zn(II) } \\
(\mu \mathrm{g} / \mathrm{L})\end{array}$ & $\begin{array}{c}\text { Recovery } \\
\text { Sn(II) } \\
(\%)\end{array}$ & $\begin{array}{c}\text { Recovery } \\
\text { Zn(II) } \\
(\%)\end{array}$ \\
\hline \multirow{3}{*}{ Blood Serum } & 0 & 0 & 10.81 & 17.0 & - & - \\
\hline & 10 & 10 & 19.92 & 27.2 & 91.1 & 102 \\
\hline & 15 & 15 & 26.42 & 31.9 & 104.06 & 99.3 \\
\hline \multirow{3}{*}{ Human hair } & 0 & 0 & 14.65 & 22.55 & 0.0 & 0.0 \\
\hline & 10 & 10 & 24.0 & 33.0 & 93.5 & 104.5 \\
\hline & 15 & 15 & 30.0 & 37.9 & 102.33 & 102.33 \\
\hline
\end{tabular}

\section{Conclusion}

The present study demonstrated that the adsorptive stripping analysis of tin and zinc in the presence of HBO (2,2hydroxyphenylbenzoxazole), is an excellent method for determination of trace amounts of these cations. The presented system provides a wide linear dynamic range for determination of tin and zinc in real samples (Table 3). Therefore, the presented system offers a practical method for the determination of tin and zinc, which has advantages of high sensitivity, selectivity, simplicity and speed.

Table 3a. Comparison of proposed method with other reports (for zinc).

\begin{tabular}{|c|c|c|c|c|c|}
\hline Species & Technique & Ligand & LR(M) & LOD(M) & Reference \\
\hline Zinc & AdCSV & (Morin) & $\begin{array}{l}1.54 \times 10^{-8}- \\
1.07 \times 10^{-6}\end{array}$ & $9.2 \times 10^{-10}$ & 7 \\
\hline Zinc & $\begin{array}{l}\text { SWASV } \\
\text { with } \\
\text { Bismuth } \\
\text { film }\end{array}$ & & 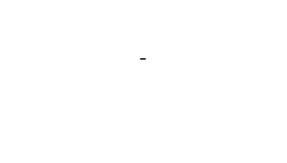 & $0.6 \times 10^{-9}$ & 9 \\
\hline Zinc & electrode & & $\begin{array}{l}1.53 \times 10^{-8}- \\
2.77 \times 10^{-7}\end{array}$ & $1.07 \times 10^{-8}$ & 10 \\
\hline Zinc & $\begin{array}{l}\text { DPASV } \\
\text { with glassy } \\
\text { carbon } \\
\text { electrode }\end{array}$ & & $\begin{array}{c}8.00 \times 10^{-9}- \\
2.5 \times 10^{-7}\end{array}$ & $1.98 \times 10^{-8}$ & 11 \\
\hline Zinc & DPASV & $\mathrm{HCl} 0.1 \mathrm{M} \mathrm{pH} 4$ & - & $1.99 \times 10^{-10}$ & 12 \\
\hline Zinc & DPASV & - & $1.9 \times 10^{-8}-1.08 \times 10^{-6}$ & $5.00 \times 10^{-9}$ & 13 \\
\hline
\end{tabular}




\begin{tabular}{cccccc}
\hline Zinc & DPCSV & $\begin{array}{c}\text { Ammonia/ammonium } \\
\text { chloride pH } 9.4\end{array}$ & $1.00 \times 10^{-9}-8.99 \times 10^{-7}$ & $1.11 \times 10^{-10}$ & 14 \\
Zinc & ADCSV & Pyrophosphate pH 4.0 & $1.5 \times 10^{-6}-6.1 \times 10^{-6}$ & $0.22 \times 10^{-6}$ & 17 \\
Zinc & DPASV & HBO & $1.5 \times 10^{-9}-1.3 \times 10^{-6}$ & $0.15 \times 10^{-9}$ & This work \\
& & & & \\
\hline
\end{tabular}

Table 3b. Comparison of proposed method with other reports (for tin)-

\begin{tabular}{|c|c|c|c|c|c|}
\hline Species & Technique & Ligand & LR(M) & LOD(M) & Reference \\
\hline Tin & $\begin{array}{l}\text { UV/Visible } \\
\text { Spectrophotometric }\end{array}$ & Bromopyrogallol(BPR) & $8.4 \times 10^{-7}-2.1 \times 10^{-5}$ & $1.5 \times 10^{-7}$ & 16 \\
\hline Tin & DPASV & $\begin{array}{l}\text { Oxalic acid-Methylen } \\
\text { blue }\end{array}$ & $1.6 \times 10^{-7}-8.4 \times 10^{-6}$ & $8.4 \times 10^{-6}$ & 17 \\
\hline Tin & Spectrofluorometry & $\begin{array}{l}\text { 1-(2-pyridylazo)-2- } \\
\text { naphtol(PAN) }\end{array}$ & $8.4 \times 10^{-9}-6.7 \times 10^{-6}$ & - & 18 \\
\hline Tin & DPASV & Chloranilic acid & $2.1 \times 10^{-9}-2.1 \times 10^{-7}$ & $1.9 \times 10^{-7}$ & 19 \\
\hline Tin & $\begin{array}{l}\text { Electrochemical } \\
\text { hydride } \\
\text { generation atomic } \\
\text { fluorescence } \\
\text { spectrometry }\end{array}$ & - & - & $1.2 \times 10^{-8}$ & 20 \\
\hline Tin & DPASV & - & $8.4 \times 10^{-9}-8.4 \times 10^{-7}$ & $7.5 \times 10^{-9}$ & 21 \\
\hline Tin & DPASV & $\begin{array}{l}\text { Bromopyrogallol red } \\
\text { (BPR }\end{array}$ & $8.4 \times 10^{-9}-4.2 \times 10^{-7}$ & $5 \times 10^{-10}$ & 22 \\
\hline Tin & $\begin{array}{l}\text { Hydride } \\
\text { generation- } \\
\text { inductivity } \\
\text { coupled plasma } \\
\text { atomic emission } \\
\text { spectrometry(ICP }\end{array}$ & $\begin{array}{l}\text { Dibasic ammonium } \\
\text { citrate buffer } \mathrm{pH} 6.5\end{array}$ & $01 \times 10-622 \times 10-5$ & $8.4 \times 10^{-10}$ & 23 \\
\hline Tin & $\begin{array}{l}\text {-OES) } \\
\text { SWASV }\end{array}$ & - & $2.1 \times 10^{-6}-2.3 \times 10^{-5}$ & $1.0 \times 10^{-6}$ & 24 \\
\hline Tin & $\begin{array}{l}\text { Spectrophotometr } \\
\text { ic }\end{array}$ & $\begin{array}{l}\text { Diacetylmonoxime p- } \\
\text { hydroxybenzoylhydrazo } \\
\text { ne(cationic micellar } \\
\text { medium) }\end{array}$ & $0.008-0.5 \mathrm{mg} / \mathrm{L}$ & - & 25 \\
\hline Tin & DPASV & $0.2 \mathrm{M} \mathrm{HNO}_{3}$ & & $2.5 \times 10^{-8}$ & 26 \\
\hline Tin & $\begin{array}{l}\text { Gas Phase } \\
\text { chemiluminescen } \\
\text { ce's with ozone } \\
\text { oxidation -Flow } \\
\text { injection hydride } \\
\text { generation and } \\
\text { cryotrapping }\end{array}$ & & & $2.6 \times 10^{-9}$ & 27 \\
\hline Tin & DPASV & $\mathrm{HBO}$ & $0.4 \lambda 10-0.4 \lambda 10$ & $7.5 \times 10^{-10}$ & This work \\
\hline
\end{tabular}




\section{Acknowledgments}

The authors would like to acknowledge the Vice Chancellor of Hamadan University of Medical Sciences for the funding and support of the study (Project No. 9807305617).

\section{References}

[1] S.M. Sabry, A.-A. M. Wahbi, Anal. Chim. Acta., 1999, 401, 173-183.

[2] S. Sobhanardakani, A. Farmany, S. Abbasi, J Industr Eng Chem, 2014, 20, 3214-3216.

[3] J. Davies, H. Berndt, Anal. Chim. Acta., 2003, 479, 215-223.

[4] C.C. Nascentes, M.A.Z. Arruda, A.R.A. Nogeira, J.A. Nobrega, Talanta, 2004, 64, 912-917.

[5] S. Fernández-Menéndez, M.L. Fernández-Sánchez, B. FernándezColomer, R.R. de la Flor St Remy, G.D. Cotallo, A.S. Freire, B.F. Braz, R.E. Santelli, A. Sanz-Medel, J Chromatogr A, 2016, 1428, 246-254.

[6] E. Shams, A. Babaei, M. Soltaninezhad, Anal. Chim. Acta., 2004, 501, 119-124.

[7] C. Colombo, C.M.G. van den Berg, Anal. Chim. Acta, 1997, 337, 29-40.

[8] S. Abbasi, A. Farmany, S.S. Mortazavi, Electroanalysis, 2010, 22, 2884-2888.

[9] J.F. van Staden, M.C. Matoetoe, Anal. Chim. Acta., 2000, 411, 201-207.

[10] M. Firmino de Oliveira, A.A. Saczk, L.L. Okumura, A.P. Fernandes, M. de Moraes, N.R. Stradiotto, Anal. Bioanal. Chem., 2004, 380, 135-140.

[11] M.M. Ghoneim, A.M. Hassanein, E. Hammam, A.M. Beltagi, Fresenius J. Anal. Chem., 2000, 367, 378-383.

[12] O.A. Farghaly, Microchem. J., 2003, 75, 119-131.

[13] C. Locatelli, G. Torsi, Microchem. J., 2000, 65, 293-303.
[14] M.B. Gholivand, F. Ahmadi, A. Sohrabi, Electroanalysis, 2007, 23, 2465-2471.

[15] P. Zuman, Electroanalysis, 2000 , 12, 1187-1194.

[16] S B. Adeloju, Anal. Sci., 1991, 7, 1099-1103.

[17] J. Wang, J. Zadeii, Talanta, 1987, 34, 909-1014.

[18] C.M.G. van den Berg, S.H. Khan, J.P. Riely, Anal. Chim. Acta., 1989, 222, 43-54.

[19] F. Heppeler, S. Snder, G. Henze, Anal. Chim. Acta., 1996, 319, 19-24.

[20] Y.H. Lee, X.F. Duan, Fenxi Hиахие, 1990, 18, 44-49.

[21] N.V. Tobolkina, N.D. Fedorova, K.Z. Brainina, Zavod. Lab., 1992, 58, 5-13.

[22] Z.Q. Gao, K.S. Siow, Anal. Sci., 1996, 12, 267-272.

[23] X. Huang, W. Zhang, S. Han. X. Wang, Talanta, 1997, 44, 817-822.

[24] J.F.V. Staden, M.C. Matoeto, Anal. Chim. Acta., 2000, 411, 201-207.

[25] L. Qiong, L. Guanghan, W. Heng, W. Xiaogang, Food Chem., 1999, 64, 129-132.

[26] J.L. Manzoori, M. Amjadi, D.J. Abdolhasani, J. Hazard. Mater., 2006, 137, 1631-1635.

[27] F. Heppeler, S. Sander, G. Henze, Anal. Chim. Acta., 1996, 319, 19-24.

[28] Y.K. Jang, D.E. Kim, W.S. Kim, O. K. Kwon, B.J. Lee, Y.S. Kwon, Colloids and Surfaces, 2006, 284-285, 331-334.

[29] R. Heidarimoghadam, O. Akhavan, E. Ghaderi, E. Hashemi, S.S. Mortazavi, A. Farmany, Mater Sci Eng C, 2016, 61, 246-250.

[30] R. Heidarimoghadam, A. Farmany, Mater Sci Eng C, 2016, 58, 1242-1245.

[31] W.H. Elobeid, A.A. Elbashir, Progress in Chemical and Biochemical Research, 2019, 2, 24-33. 
How to cite this manuscript: Shahryar Abbasi, Somayeh Hamdeghadareh, Loghman Rezaei, Abbas Farmany. 2,2-Hydroxyphenylbenzoxazole as a selective chelating agent for complexation with Tin and Zinc: a voltammetry study. Eurasian Chemical Communications, 2020, 2(1), 128-137. 